\title{
Exceptions of Banking Secrets for The Interest of Taxes in Indonesia (a Comparation of The Post- Birth of Access Law to Financial Information)
}

\author{
Upik Mutiara $^{1 *}$, Ika Khairunnisa Simanjuntak ${ }^{2}$, Rahmad Ramadhan \\ Hasibuan ${ }^{3}$ Amiludin ${ }^{4}$
}

${ }^{1,4}$ Faculty of Law, Post Graduate of Law, University of Muhammadiyah Tangerang,. Tangerang, Banten, 15118, Indonesia

${ }^{2}$ Faculty of Law, University of Medan Area, Medan, North Sumatera, 20223, Indonesia

${ }^{3}$ Faculty of Law, University of Indonesia, Depok, West Java, 16424, Indonesia

*Corresponding author: upikmutiara.umt@gmail.com

\begin{tabular}{|c|c|}
\hline$\overline{\text { Arti }}$ & Abstract \\
\hline $\begin{array}{l}\text { Article History } \\
\text { Received: Augt 28, 2020; } \\
\text { Reviewed: Sept 6, 2020; } \\
\text { Accepted: Sept 16, 2020; } \\
\text { Published: Sept 30, } 2020\end{array}$ & $\begin{array}{l}\text { Act Number } 7 \text { of } 1992 \text { as amended by Act Number } 10 \text { of } 1998 \text { concerning } \\
\text { Banking and several related rules already regulates the exclusion of banking } \\
\text { secrets, especially for tax purposes. However, the existing mechanism has not been } \\
\text { able to accommodate the exchange of financial information within the framework } \\
\text { of the Automatic Exchange of Information (AEOI). Then the Financial } \\
\text { Information. Access Act was formulated which regulates the automatic exchange } \\
\text { of financial information that has never been known before. The problems } \\
\text { discussed in this study, how are the exceptions of bank secrets for tax purposes } \\
\text { that have been carried out in Indonesia and how are bank secrets exceptions } \\
\text { regulated in the Financial Information Access Act. The research method used is } \\
\text { a normative juridical method with a descriptive analytical research approach. The } \\
\text { results of the study found that the exception of bank secrets has long been known } \\
\text { in Indonesia but is still limited by a convoluted bureaucracy. Whereas in the } \\
\text { Financial Information Access Act, exceptions take place automatically but there } \\
\text { are sanctions for those who misuse information. }\end{array}$ \\
\hline \multicolumn{2}{|c|}{$\begin{array}{l}\text { (C)2020; This is an Open Acces Research distributed under the term of the Creative Commons } \\
\text { Attribution Licencee (https://Creativecommons.org/licences/by/4.0), which permits unrestricted } \\
\text { use, distribution, and reproduction in any medium, provided the original works is properly cited. }\end{array}$} \\
\hline
\end{tabular}

\section{INTRODUCTION}

In 2018, Indonesia participated in the Automatic Exchange of Information (AEOI) for tax purposes through an automatic exchange of bank customer data with other countries (Beer et al., 2019; Knobel \& Meinzer, 2014). This participation was 
based since after Indonesia signed the Convention on Mutual Administrative Assistance in Tax Matters (MAAC) which is a multilateral instrument that facilitates the AEOI implementation (Mosquera Valderrama, 2015; Wilson, 2016). The MAAC which was signed by Indonesia as the participant in the AEOI was then ratified into the Republic of Indonesia's Presidential Regulation Number 159 of 2014 concerning Ratification of the Convention on Mutual Administrative Assistance in Tax Matters (Hasim et al., 2018; Simanjuntak, 2020a). AEOI or automatic exchange of information for tax purposes began to emerge in 2010 when the United States (U.S.) government issued a Foreign Account Tax Compliance Act (FATCA) policy that required Foreign Financial Institutions (FFIs), i.e. financial institutions outside of the US (Simanjuntak, 2020a). It aims to carry out reporting to the US government regarding information of financial accounts that are owned by US residents or other entities in which the US citizens holds a substantial ownership interest (Wijaya, 2019).

In the era of disclosure information which is pioneered by the US in FATCA above, was later followed by other countries (Blank \& Mason, 2014; Eccleston \& Gray, 2014). In 2013, the Minister of Finance of Indonesia and the Governor of the Central Bank from the G20 member countries and the Organization for Economic Cooperation and Development (EOCD) agreed to formulate policies such as FATCA through the Common Reporting Standards (CRS) as the basis for global information exchange. The OECD publication on July 26 2016 provided information that there were 101 jurisdictions have committed to implement AEOI, there were 54 of them have begun exchanging information automatically in 2017, including Indonesia who began to implement it in 2018 (Christians, 2010).

The AEOI is an automatic system of exchanging account information from taxpayers between countries. It means that the taxpayers' accounts in other countries can be directly tracked by the tax authorities in one country when the rule is enforced (Harjayani \& Indriyana, 2019; Hartina, 2019). At first, Indonesia was still in Partially Compliance status in implementing AEOI (Simanjuntak, 2020a). Partially Compliance is defined as "The essential element is only partly implemented" with Non-Compliant, or as a country who does not yet meet the requirements in element B.1 regarding Access Powers (bank secrecy)(Banks, 2010). The applied status is due to the existence of a legal regulation, namely Law Number 10 of 1998 concerning Banking (hereinafter referred to as the Bank Act) which regulates the obligation to keep the depositor's information and deposit information confidential, it is also known as Bank Confidentiality principle (Ayza, 2017; Selvi, 2018). In terms of rules and practices, the obligations on banking secrecy can still be excluded for certain circumstances and interests, especially in the taxation. However, the regulation of 
exceptions in existing banking secrets does not support the implementation of AEOI (Bustamar Ayza, 2016; Insan \& Maghijn, 2018).

This is why Indonesia is delaying the implementation timeline for AEOI until 2018 and issued Government Regulation in Lieu of Law Number 1 of 2017 on Access to Financial Information for Tax Purposes that had been ratified into Law through Law Number 9 of 2017 on Stipulation Government Regulation in Lieu of Law Number 1 of 2017 Concerning Access to Financial Information for Taxation Purposes into Law (Act on Access to Financial Information) (Oktavia et al., 2019; Sholihah et al., 2018). This regulation is a national legal protection for the implementation of AEOI in Indonesia, which in its content provides tax authorities from the Directorate General of Taxes to access financial information (Anggia, 2020; Krustiyati \& Hugeng, 2019).

On the other hand, this regulation also excludes and states that the principle of banking secrecy does not apply to taxation purposes. In fact, bank secrecy is the life of banking activities that must be maintained in order to avoid data leakage which will harm customers (Santoso, 2019, 2020). On the other hand, AEOI does require bank secrecy arrangements that can support its implementation effectively and efficiently (Ekawati, 2018; Muhaimin, 2019). Regarding to these matters, the writer conducted a research on how bank secrets were excluded for tax purposes that had been carried out in Indonesia and how excluding secrets of bank were regulated in the Financial Information Access Act.

\section{METHOD}

This study uses normative juridical research methods (legal research), which the research is focused on examining the application of rules or norms in positive law in force (M. Marzuki, 2017; P. M. Marzuki, 2010). While the research approach method used in this legal research is analytical descriptive. Analytical descriptive research is research that aims to draw and analyze the data facts systematically, factually, and accurately, as well as the relationship of the phenomenon under investigation (Diantha, 2016; Gumilang, 2016). On the other hand, secondary data sources obtained from library research, both are collected in the form of primary legal materials, secondary legal materials and tertiary legal materials as the main data, or primary data research. 


\section{RESULTS AND DISCUSSION}

\section{The Exclusion of Bank Secrets for Tax Purposes in Indonesia}

The relationship between the bank and the customer is based on a trust. This trust encourages customers to deposit their money because they believe that the bank can maintain their savings and financial condition which is not misused and distributed to other parties (Pramana \& Rastini, 2016; Suhardi, 2017). This trust is then supported by the emerging of obligations that must be performed by banks to keep their customers information confidential. In addition, customers also have personal rights (privacy rights) that have been considered as human rights and brought since humans were born, especially relating to their personal or financial secrets (financial privacy) (Anggianti \& Suardana, 2016; Ledesman, 2018). So it is not an excessive one if the confidentiality is considered as the soul of banking activities because without the confidentiality of banking as the collector and distributor of public funds, the activities cannot be done (Simanjuntak, 2020b).

Basically, banking began to grow in Europe with the philosophy that bank secrecy is a primary thing as the foundation of business ethics between banks and customer trust, which is subject to "The contractual duty is implied by law under the contract between a bank and its customer" (Murni et al., 2019; Pamuji, 2017; Suristyo, 2018). Protection of bank secrets that are considered as a prime is important to be regulated in the legislation. The obligation to keep the customers' confidentiality is regulated in Article 40 of Act Number 10 of 1998 concerning Amendment to Act Number 7 of 1992 concerning Banking which reads: "A Bank shall keep information concerning Deposit Customer and their Deposits confidential, except those stipulated in Article 41, Article 41A, Article 42, Article 43, Article 44, and Article 44A" (Rani, 2014; Sarapi, 2013). According to the article, it is clearly stated that the principle of bank secrecy in Indonesia recognizes restrictions and excuses in its application or also known as bank secrecy which is relative. The relativity of banking secrets means that there are possibilities to open the bank secrets in certain ways for the public interest (Setiawan, 2020; Zaini, 2019).

This relativity then becomes an alternative when the absolute nature of bank secrets is vulnerable to be the object of saving money to hide from crimes because the absolute nature of bank secrecy provisions cannot be alleviated for any reason (Abdullah et al., 2019). With regard to this relative nature, the Banking Law also regulates bank exceptions (Lestari, 2019). The exceptions to bank secrecy are regulated in the Banking Law are as follows (Keuangan, 2016):

1. For taxation purposes, an exemption can be given to the tax officials based on the orders of the Governor of Bank Indonesia by the request of the Minister of Finance of Indonesia (Article 41);

2. For the settlement of bank receivables that have been submitted to the Committee of State Receivables Management, the exceptions can be given to the 
Committee of State Receivables Management under the permission of the Management of Bank Indonesia (Article 41A);

3. For the court interests in criminal cases, the exceptions can be given to the police, prosecutors, or judges under the permission of the Chairmen of Bank Indonesia (Article 42);

4. In civil cases, between the banks and customers, the exceptions can be granted without the license from the Chairmen of Bank Indonesia (article 43);

5. In the context of exchanging information, between banks and other banks, the exceptions can be granted without the permission of the Management of Bank Indonesia (Article 44);

6. Under the approval, the request or power of attorney from the depositing customer may be given the exceptions without the permission from the Chairmen of Bank Indonesia in written notification (Article 44A paragraph (1));

7. at the request of a legal heir of a deceased customer who has deposited his/her funds (Article 44A paragraph (2));

The exceptions of bank secrecy in Indonesia are limitative. It means that outside of these matters, banks are not permitted for any reason whatsoever to give information to anyone regarding their depositors and deposits. The exception of bank secrets in the field of taxation are regulated on the grounds to make it easier to uncover cases of tax evasion, money loundering with tax crim as a predicate crime and smuggling. Based on the general provisions and Taxation procedures law "Undang-undang Ketentuan umum dan Tata cara perpajakan/ UU KUP" Law No. 6/1983, amended by no. 16/2009 (Mooduto, 2013; Rosa Lestari, 2017). As you know, tax collection in Indonesia refers to the Self-Assessment system (Sudadyo, 2013; Wulandari, 2017). Self-Assessment is a tax collection system that gives the authority, trust and responsibility to taxpayers to calculate, pay, and report for themselves the amount of tax that must be paid. Basically, Self-Assessment depends on the awareness of taxpayers to pay their taxes, the honesty of taxpayers to calculate their own taxes is in accordance with their financial condition. As a consequence, there has been an ups and downs in the number of the annual tax return submitted by taxprayers.

Referring to Directorate of taxes 2018 annual report, it was showed that the compliance ratio in 2018 (71.10\%) was lower than 2017 (72.58\%) Compliance rate is the ratio of annual income tax return successfully submitted to total tax payers obliged to submit a tax return. The figure below shows that the number of taxpayers from 2017 to 2018 went up by 1.054 .159 taxpayers. The annual income tax return, on the other hand showed a little change from 12,047,967 in 2017 to 12,551,444 in 2018. As a result the compliance rate in 2018 was decreased. (Annual Report 2018, 
Officially presented by the Ministry of Finance of Republic Indonesia). However, in reality there were quite a number of people who deliberately or for various reasons did not carry out their obligations to pay taxes according to the tax assessments issued (Masruroh \& Zulaikha, 2013; Supadmi, 2012).

The form of tax avoidance carried out by the public is by placing their Income Taxes at domestic and foreign banking institutions which are protected by the principle of bank secrecy (Sikka \& Willmott, 2010; Zucman, 2014) To accommodate this problem, basically the Banking Law has accommodated the exception of bank secrets for the public interest in the taxation sector, namely Article 41 paragraph (1) and (2) "In the interest of taxation, the Chairmen of Bank Indonesia is entitled to issue a written order to a Bank to disclose information and produce written evidence and documents concerning the financial condition of a particular Deposit Customer to a taxation officer". Written orders as referred to in paragraph (1), must mention the name tax official and name of the desired taxpayer.

The exception can only be applied with certain terms and conditions that have been limited by the Banking Act. One of the elements that must be fulfilled is the opening of bank secrets for tax purposes. See also Article 42 paragraph (1) of Law Number 21 of 2008 concerning Sharia Banking which regulates that the opening / breaching of bank secrets for tax purposes is not broadly defined, but is limited to tax criminal investigations. The technical procedures for disclosing bank secrets are in Bank Indonesia Regulation Number 2/9 / PBI / 2000 concerning Requirements and Procedures for Granting or Written Permits to Open Bank Secrets. Arranged in the provisions of Article 2 paragraph (4) the exception obligation to keep customer funds confidential, one of which is for tax purposes. Next, Article 3 paragraph (1) stipulates the technical implementation of bank secrecy for tax purposes, namely, it is required to first request written instructions or permits for Bank Secrecy from the Management of Bank Indonesia. Since the enactment of the Financial Services Authority Act, the authority to grant approval relating to bank secrets that was granted by the Management of Bank Indonesia, has been transferred to the Head of the Financial Services Authority.

Furthermore, in the Regulation of the Minister of Finance of the Republic of Indonesia Number 87 / PMK.03 / 2013 concerning Procedures for Requests for Information or Evidence from Parties Bound by the Obligation to Keep a Secret (PMK No. 87 / PMK.03 / 2013) also regulates the procedures and requesting processes for documents, evidence, or information related to tax collection from a bound Third Party, in this case a bank, with an obligation to keep confidential. This provision stipulates that the process of requesting data or information from banks 
must be based on a request from the Minister of Finance to the Governor of Bank Indonesia as stipulated in the Banking Law.

The written request of the Minister of Finance must contain matters as regulated in Article 2 paragraph (1) PMK No. 87 / PMK.03 / 2013, as follows:

1. Taxpayer identity;

2. Information and / or evidence requested;

3. The purpose of the request for information and / or evidence.

The bank is obliged to provide the requested data, evidence, or information regarding the audited taxpayer, after the Tax Auditor, equipped with a written request from the Minister of Finance, submits the documents, evidences and information required to the bank. Based on Article 2 paragraph (2) PMK No. 87 / PMK.03 / 2013, the bank is obliged to provide the documents, evidences, or information requested no later than 7 days from the receipt of the request for information or evidence or a permit from the competent authority.

Refusal to provide confidential data, documents, or evidence may result in a violation of criminal law (Wibisono \& Gunawan, 2013). On the other hand, Banks are prohibited to provide information on the financial condition of a depositing customer other than those stated in an order or written permission from Bank Indonesia. The bank can only provide information both orally and in writing, by showing written evidences, letters, and printed electronic data regarding the financial condition of the depositing customer as stated in the written or license order submitted to the bank. A new mechanism in the exception of banking secrets for tax purposes has also been known in PMK-125 / PMK.010 / 2015, which positioning the customers as the determinant of whether or not to open access to financial information. This mechanism is an effort to accommodate AEOI before the issuance of the Access to Financial Information Act, however, it must obtain prior permission by the customer and be based on a statement letter from the taxpayer customer of the Partner Country or Partner Jurisdiction.

Based on the explanation above, both the Banking Law, Bank Indonesia Regulation Number 2/9/PBI/2000, PMK Number 87/PMK.03/2013, and PMK125/PMK.010/2015 are basically in line in providing regulations. the process of opening banking secrets for tax purposes. However, its application must follow the legal principles of lex specialis derogate lex generalis because the effectiveness of the implementation of bank secret disclosure systems for tax purposes, of course, also needs to be supported by good cooperation between the Ministry of Finance, Bank Indonesia, and related bank parties (Simanjuntak, 2020b). 
However, the provisions concerning bank secrecy left some problems in the implementation. This occurred because of differences of interests between banking institutions and the Directorate General of Taxes (DGT). On the one hand, banking institutions need funds from the public and always need increased funds that go into third party funds, on the other hand, DGT also has a target regarding the amount of tax revenue for each outcome. Therefore, there are several challenges that exist in secret banks:

1. The bureaucratic licensing process took a long time and was complicated;

2. Legal uncertainty regarding the license to disclose bank secrets;

3. Fear of Banks to open bank secrecy, fear of fear, fear of disappearance or losing departure;

4. Limitations of the Directorate General of Taxes to access taxpayer data.

Apart from these problems, there was also the fact that the Directorate General of Taxation has limited comparisons to test the correctness of taxpayer documents, books and/or records. The interest in tax collection was also limited to the examination, investigation, and collection of taxes only (Kautsar, 2015). So, it can be concluded, although in terms of regulations in the field of taxation it was privileged to open banking secrets, the application still faced various kinds of obstacles.

\section{The Conception of Exceptions to Banking Secrecy in the Law on Access to Financial Information in Implementing AEOI}

In the implementation of AEOI, Indonesia will be bound by the principle of reciprocity or the same treatment as other countries. This means that when banks in other countries open their customer data in Indonesia, banks in Indonesia must do the same to open their customer data for the needs of other countries (Nabila \& Dhiya, 2020). This principle causes the AEOI cooperation implemented by Indonesia to have two dimensions, namely Indonesia as the country providing information and Indonesia as the country receiving information (Simanjuntak, 2020b).

In the first dimension, DGT can provide data and information regarding butchering income tax on foreign tax subjects who receive income originating from Indonesia. This data and information were obtained directly from the taxpayer who deducted and reported the income tax on this income. In addition, DGT can also provide financial data and information for customers of financial institutions, including banks. Data and information regarding banking customer identities in the form of names, account numbers, domestic addresses, and calendar year end balances can be subject to AEOI with partner countries. However, such data and information must first be approved by the customer, then submitted by the bank to 
the financial institution authority, which will then submit the data and information to the DGT.

In the second dimension, DGT can automatically receive data and information from partner countries as a basis for carrying out the necessary law enforcement efforts. In addition to acting passively, DGT can also submit requests for information to partner countries regarding the activities of domestic taxpayers in the territories of partner countries. The request for information must be made within the framework of law enforcement that is carried out by DGT against the taxpayer, for example, a tax audit or preliminary evidence examination.

In the Law on Access to Financial Information, it is stated that the DGT has the authority to obtain financial access for tax purposes in accordance with the exchange standards for financial information based on international agreements in the field of taxation. To support this, banking institutions are required to inform the DGT regarding:

1. Reports containing financial information in accordance with financial information exchange standards based on international agreements in the field of taxation for each financial account identified as a financial account that must be reported;

2. Reports containing financial information for tax purposes, which are managed by banking institutions for one-year calendar.

The reports provided article 2 paragraph (3) of the Law on Access to Financial Information include the following:

a. the identity of the financial account holder;

b. financial account number;

c. identity of financial service institutions;

d. balance or value of financial accounts; and

e. income related to financial accounts.

To carry out this, in the event that a banking institution is bound by a confidentiality obligation based on the provisions of laws and regulations, the confidentiality obligation does not apply. This data was based on Indonesia's participation in the AEOI, so the Minister of Finance had the right to exchange the data with other countries that were also bound by international agreements. On the basis of this implementation, the Minister of Finance cannot be prosecuted criminally and sued in a civil manner, this also applies to leaders and employees of the banking institution concerned. 
This rule also imposes sanctions on leaders or employees of banking institutions who do not submit reports, carry out proper financial account identification procedures, and provide information and/or evidence or information on financial information subject to a maximum imprisonment of one year or a maximum fine of 1 billion rupiahs. In applying this rule, serious decisiveness is needed so that it is not misused by other parties so that this laws and regulations also regulates sanctions in the form of a maximum imprisonment of one year or a maximum fine of 1 billion rupiahs for anyone who makes false statements or withholds or deducts real information of the information that must be submitted in the report.

The implementation of AEOI based on this rule has been carried out since 2018 ago. The exchange of financial information will be carried out automatically with other countries that have signed memorandums of understanding regarding AEOI. This mechanism is different from the application and restriction of banking secrets that have prevailed in Indonesia as previously described.

The constitution states that the DGT has the authority to obtain access to financial information for tax purposes from banking institutions. To avoid misuse of the information provided, the Government has also regulated sanctions for those who violate it. With this AEOI application, it is hoped that it can provide many positive benefits for Indonesia, especially in the field of state revenue and can show Indonesia's credibility in the eyes of the world in order to attract investors so that the level of Indonesia's economy continues to grow and increase every year.

\section{CONCLUSION}

Banking Law, Bank Indonesia Regulation Number 2/9/PBI/2000, PMK Number 87/PMK.03/2013 and PMK-125/PMK.010/2015 are basically in line with regulating the process of disclosing banking secrets for the purposes of taxation. However, the provisions regarding the breakthrough of bank secrecy still left problems in its implementation.

The bank secrecy exemptions stipulated in the Access to Financial Information Act are different from the previously known mechanisms. In this Law, the exchange of financial information with other countries is carried out automatically with countries that have signed memorandums of understanding regarding AEOI. The mechanism is different from the exception of bank secrecy with the bureaucratic mechanisms and permits that have been applied in Indonesia. 


\section{REFERENCES}

Abdullah, M. Z., Ibrahim, I., \& Hidayat, I. (2019). Faktor-Faktor Yang Mempengaruhi Perlu Dilakukan Kebijakan Regulasi dalam Penanggulangan Tindak Pidana Di Bidang Perbankan. Legalitas: Jurnal Hukum, 11(2), 229-257.

Anggia, P. (2020). The Influence of International Tax Policy on the Indonesian Tax Law. Yuridika, 35(2), 343-362.

Anggianti, N. K. D., \& Suardana, I. W. (2016). Pengaturan Prinsip Kepercayaan Dalam Melakukan Transaksi Keuangan Pada Bank.

Ayza, B. (2017). Pertukaran Informasi Keuangan Secara Otomatis (Automatic Exchange Of Financial Account Information (AEOI) Untuk Kepentingan Perpajakan (Selisik Tentang: Perpu Nomor 1 Tahun 2017). Selisik: Jurnal Hukum Dan Bisnis, 3(2), 10-35.

Banks, B. T. T. C. (2010). Implementing the Tax Transparency Standards A Handbook for Assessors and Jurisdictions.

Beer, S., Coelho, M., \& Leduc, S. (2019). Hidden treasure: The impact of automatic exchange of information on cross-border tax evasion.

Blank, J. D., \& Mason, R. (2014). Exporting FATCA.

Bustamar Ayza, S. H. (2016). Hukum Pajak Indonesia. Kencana.

Christians, A. (2010). Taxation in a Time of Crisis: Policy Leadership from the OECD to the G20. Nw. JL \& Soc. Pol'y, 5, 19.

Diantha, I. M. P. (2016). Metodologi penelitian bukum normatif dalam justifikasi teori bukum. Prenada Media.

Eccleston, R., \& Gray, F. (2014). Foreign accounts tax compliance act and American leadership in the campaign against international tax evasion: Revolution or false dawn? Global Policy, 5(3), 321-333.

Ekawati, D. (2018). Perlindungan Hukum Terhadap Nasabah Bank Yang Dirugikan Akibat Kejahatan Skimming Ditinjau Dari Perspektif Teknologi Informasi Dan Perbankan. UNES Law Review, 1(2), 157-171.

Gumilang, G. S. (2016). Metode penelitian kualitatif dalam bidang bimbingan dan konseling. Jurnal Fokus Konseling, 2(2).

Harjayani, P., \& Indriyana, P. (2019). Pengaruh Sistem Automatic Exchange Of Information (Aeoi), Sistem Administrasi Perpajakan Modern, Dan Pemeriksaan Pajak Terhadap Kepatuban Pajak [PhD Thesis]. IAIN SURAKARTA. 
Hartina, U. (2019). Pengampunan Pajak (Tax Amnesty) di Indonesia Perspektif Hukum Ketatanegaraan Islam [PhD Thesis]. Universitas Islam Negeri Alauddin Makassar.

Hasim, M. P., Priyono, F. J., \& Sa'adah, N. (2018). Karakter Multilateral Competent Authority Agreement On Automatic Exchange Of Financial Account Information Dan Implikasinya Pasca Program Tax Amnesty Di Indonesia. Diponegoro Law Journal, 7(4), 345-363.

Insan, I. H., \& Maghijn, T. N. (2018). Penerapan Pengampunan Pajak (Tax Amnesty) Di Indonesia Berdasarkan Undang-Undang Nomor 11 Tahun 2016 Beserta Permasalahannya. Pakuan law review, 4(2).

Kautsar, R. (2015). Membuka Kerahasiaan Bank untuk Kepentingan Perpajakan dengan Alasan Pemberian Akses Langsung Kepada Aparat Pajak Indonesia dan Pemberlakuan Foreign Account Tax Compliance Act di Indonesia. Fakultas Hukum Universitas Indonesia.

Keuangan, O. J. (2016). Booklet Perbankan Indonesia. Jakarta: OJK.

Knobel, A., \& Meinzer, M. (2014). Automatic exchange of information: An opportunity for developing countries to tackle tax evasion and corruption. Tax Justice Network, 1-57.

Krustiyati, J. A., \& Hugeng, D. (2019). Obligations for Indonesian Banks to Report Its Customers Data to Tax Office Under Automatic Exchange of Information (AEOI) Stipulations. Social and Humaniora Research Symposium (SoRes 2018).

Ledesman, M. (2018). PENGARUH MANFAAT, KEPERCAYAAN, DAN KEMUDAHAN PENGGUNAAN TERHADAP MINAT NASABAH MENGGUNAKAN LAYANAN MOBILE BANKING (Studi Pada BSM Cabang Bandar Jaya) [PhD Thesis]. UIN Raden Intan Lampung.

Lestari, T. A. (2019). KEWENANGAN KOMISI PEMBERANTASAN KORUPSI (KPK) DALAM PENGECUALIAN KERAHASIAAN BANK. SUPREMASI HUKUM, 15(1), 63-71.

Marzuki, M. (2017). Penelitian Hukum: Edisi Revisi. Prenada Media.

Marzuki, P. M. (2010). Penelitian Hukum, Cet. VI, Kencana Prenada Media Group, Jakarta, Hal, 93.

Masruroh, S., \& Zulaikha, Z. (2013). Pengaruh Kemanfaaatan Npwp, Pemahaman Wajib Pajak, Kualitas Pelayanan, Sanksi Perpajakan Terhadap Kepatuhan Wajib Pajak (Studi Empiris pada WP OP di Kabupaten Tegal). Diponegoro Journal Of Accounting, 435-449. 
Mooduto, I. (2013). PENYELESAIAN ATAS PELANGGARAN RAHASIA BANK. LEX ET SOCIETATIS, 1(3).

Mosquera Valderrama, I. J. (2015). Legitimacy and the making of international tax law: The challenges of multilateralism.

Muhaimin, E. (2019). Urgensi rahasia bank sebagai bentuk perlindungan nasabah $[\mathrm{PhD}$ Thesis]. IAIN Metro.

Murni, R., Dharmawan, N. K. S., \& Samsithawrati, P. A. (2019). Transformasi Good Faith Principle Dalam Hukum Perbankan Khususnya BPR: Perspektif Lokal Nasional dan Internasional. Arena Hukum, 11(3), 571-599.

Nabila, M., \& Dhiya, A. (2020). Peran Automatic Exchange of Information (AEoI) sebagai Rezim Pajak Internasional dalam Upaya Menghindari Penggelapan Pajak di Indonesia [PhD Thesis].

Oktavia, I., Sukarno, H., \& Puspitasari, N. (2019). Banking Financial Performance "Before and After the Implementation of the Replacement Government Regulation Lieu of Law." International Journal of Economics \& Business.

Pamuji, R. A. (2017). Perlindungan Hukum bagi Nasabah dan Tanggung Jawab Bank terbadap Nasabah yang Mengalami Kerugian (Studi Kasus Pencurian Dana Simpanan Nasabah dengan Modus Card Skimming) [PhD Thesis]. Universitas Islam Indonesia.

Pramana, I. G. Y., \& Rastini, N. M. (2016). Pengaruh Kualitas Pelayanan Terhadap Kepercayaan Nasabah dan Loyalitas Nasabah Bank Mandiri Cabang Veteran Denpasar Bali. E-Jurnal Manajemen Universitas Udayana, 5(1).

Rani, M. (2014). Perlindungan Otoritas Jasa Keuangan Terhadap Kerahasiaan Dan Keamanan Data Pribadi Nasabah Bank. Jurnal Selat, 2(1), 168-181.

Rosa Lestari, L. (2017). Automatic Exchange Of Information Dilihat Dari Sudut Pandang Account Representative (Studi Pada Kantor Pelayanan Pajak Pramata Surabaya Gubeng Dan Kantor Pelayanan Pajak Madya Surabaya). Jurnal Akuntansi AKUNESA, 5(3).

Santoso, B. C. (2019). KETERBUKAAN INFORMASI PAJAK PASCA DIKELUARKANNYA PERPPU NOMOR 1 TAHUN 2017 TENTANG AKSES INFORMASI KEUANGAN UNTUK KEPENTINGAN PERPAJAKAN. Jurnal Pro Hukum: Jurnal Penelitian Bidang Hukum Universitas Gresik, 8(1), 110-131.

Santoso, B. C. (2020). AKIBAT ADANYA KETERBUKAAN INFORMASI PAJAK PASCA DIKELUARKANNYA PERPPU NOMOR 1 TAHUN 2017 TENTANG AKSES INFORMASI KEUANGAN UNTUK 
KEPENTINGAN PERPAJAKAN. Mimbar Keadilan Volume 13 Nomor 1 Februari 2020-Juli 2020, 12.

Sarapi, N. (2013). Usaha Bank Menjaga Rahasia Bank Dalam Rangka Perlindungan Terhadap Nasabah. Lex Et Societatis, 1(4).

Selvi, S. (2018). Automatic Exchange of Information sebagai Big Data di Bidang Perpajakan. Transparansi: Jumal Ilmiah Ilmu Administrasi, 1(1), 128-133.

Setiawan, A. (2020). TINJAUAN YURIDIS TERHADAP RAHASIA BANK DAN KEPENTINGAN PIHAK-PIHAK YANG TERKAIT. LEX PRIV ATUM, 7(5).

Sholihah, J., Susanti, D. O., \& Fahamsyah, E. (2018). Meaning of Bank Secrets After The Enacment of Law Number 9 of 2017 on Stipulation of Government Regulation in Lieu of Law No. 1 of 2017 on Access to Financial Information for the Interests Taxation Into Law.

Sikka, P., \& Willmott, H. (2010). The dark side of transfer pricing: Its role in tax avoidance and wealth retentiveness. Critical Perspectives on Accounting, 21(4), 342-356.

Simanjuntak, I. K. (2020a). Pengecualian Rahasia Perbankan untuk Kepentingan Perpajakan di Indonesia. Pena Justisia: Media Komunikasi Dan Kajian Hukum, 19(1).

Simanjuntak, I. K. (2020b). Pengecualian Rahasia Perbankan untuk Kepentingan Perpajakan di Indonesia. Pena Justisia: Media Komunikasi Dan Kajian Hukum, 19(1).

Sudadyo, H. T. (2013). Pengaruh Faktor Self Assessment System Terhadap Penerimaan Pajak Penghasilan (Studi Kasus Pada Kantor Pelayanan Pajak (KPP) Surakarta) [PhD Thesis]. Universitas Muhammadiyah Surakarta.

Suhardi, G. (2017). Faktor-faktor yang mempengarubi kepercayaan dan loyalitas nasabah perbankan di Surabaya.

Supadmi, N. L. (2012). Analisis Tingkat Pemahaman Wajib Pajak Orang Pribadi Pada Pelaksanaan Self Assesment System Dalam Melaksanakan Kewajiban Perpajakan. Jurnal Ilmiah Akuntansi Dan Bisnis, 7(1).

Suristyo, L. H. (2018). Perlindungan Hukum Terbadap Simpanan Dana Nasabah Pada Bank Tabungan Negara Di Cibubur.

Wibisono, A., \& Gunawan, C. (2013). PEMBUKAAN RAHASLA BANK UNTUK KEPENTINGAN PEMERIKSAAN PERPAJAKAN MENURUT PERUNDANG-UNDANGAN YANG BERLAKU DI INONESLA. 
Wijaya, N. K. (2019). Kontribusi tax amnesty dalam mendorong stabilitas sistem keuangan menyongsong automatic exchange of information (aeoi). INOV ASI, 15(1), 72-83.

Wilson, P. A. (2016). BRICS and International Tax Law. Kluwer Law International BV.

Wulandari, T. (2017). ANALISIS EFEKTIFITAS SELF ASSESSEMENT SYSTEM PADA PEMUNGUTAN PAJAK HO TEL DAN RESTORAN DI KOTA PEKANBARU (STUDI KASUS PADA KANTOR DINAS PENDAPATAN DAERAH KOTA PEKANBARU) [PhD Thesis]. Universitas Islam Negeri Sultan Syarif Kasim Riau.

Zaini, Z. D. (2019). Analisis Yurisdis Perlindungan Hukum Nasabah Bank terhadap Kerahasiaan Bank di Indonesia. Recital Review, 1(1), 32-49.

Zucman, G. (2014). Taxing across borders: Tracking personal wealth and corporate profits. Journal of Economic Perspectives, 28(4), 121-48. 